\title{
FAKTOR-FAKTOR PENDUKUNG AKUNTABILITAS PENGELOLAAN KEUANGAN DESA
}

\author{
Neni Nurhayati ${ }^{1}$, Dendi Purnama ${ }^{2}$, Mustika ${ }^{3}$ \\ $1,2,3$ Universitas Kuningan, Kuningan, Indonesia \\ Email korespondensi: ${ }^{1}$ neni.nurhayati@uniku.ac.id
}

\begin{abstract}
ABSTRAK
Penelitian ini bertujuan untuk menganalisis pengaruh kualitas sumber daya manusia, pengawasan Badan Permusyawaratan Desa dan partisipasi masyarakat terhadap akuntabilitas pengelolaan keuangan desa dengan sistem keuangan desa sebagai variabel intervening. Penelitian ini menggunakan metode deskriptif dan verifikatif. Populasi dalam penelitian ini adalah pemerintah desa se-Kecamatan Talaga dan Kecamatan Maja. Teknik analisis data menggunakan analisis regresi linear berganda. Hasil penelitian ini menunjukkan bahwa kualitas sumber daya manusia (SDM), pengawasan Badan Permusyawaratan Daerah (BPD), partisipasi masyarakat, dan sistem keuangan desa secara parsial berpengaruh positif terhadap akuntabilitas pengelolaan keuangan desa. Kualitas SDM dan pengawasan BPD berpengaruh positif terhadap akuntabilitas pengelolaan keuangan desa sedangkan partispasi masyarakat tidak berpengaruh terhadap sistem keuangan desa. Sistem keuangan desa mampu memediasi kualitas SDM, pengawasan BPD dan partisipasi masyarakat terhadap akuntabilitas pengelolaan keuangan desa. Implikasi dari penelitian ini untuk mewujudkan asas pengelolaan keuangan desa yang akuntabel diperlukan SDM yang berkualitas, Badan Permusyawartan Desa bertugas mengawasi secara baik dan selalu melibatkan masyarakat dalam rapat perencanaan pembangunan maupun pelaksanaan pembangunan desa jangka pendek maupun jangka panjang dan mengungkapkan penggunaan dana secara akuntabel dan transparan.
\end{abstract}

Kata Kunci: akuntabilitas; kualitas sumber daya manusia; partisipasi masyarakat; sistem keuangan desa

\begin{abstract}
This study aims to analyze the influence of the quality of human resources, supervision of the Village Consultative Body and community participation on the accountability of village financial management with the village financial system as an intervening variable. This research uses descriptive and verification methods. The population in this study is the village government in Talaga and Maja sub-districts. The data analysis technique used multiple linear regression analysis. The results of this study indicate that the quality of human resources (HR), supervision of the Regional Consultative Body (BPD), community participation, and the village financial system partially have a positive effect on village financial management accountability. The quality of human resources and supervision of the BPD has a positive effect on the accountability of village financial management, while community participation has no effect on the village financial system. The village financial system is able to mediate the quality of human resources, BPD supervision and community participation in the accountability of village financial management. The implication of this research is that to realize the principle of accountable village financial management, quality human resources are needed. The Village Consultative Body is tasked with supervising properly and always involving the community in development planning meetings and implementing short and long-term village development and disclosing the use of funds in an accountable and transparent manner.
\end{abstract}

Keywords: accountablity; community participation; human resources quality; village's financial system

\section{KETERANGAN ARTIKEL}

Riwayat Artikel: diterima: 17 Oktober 2021; direvisi: 6 Desember 2021; disetujui: 24 Desember 2021

Klasifikasi JEL: H83

Cara mensitasi: Nurhayati, N., Purnama, D., \& Mustika. (2021). Faktor-faktor Pendukung Akuntabilitas Pengelolaan Keuangan Desa. JIAFE (Jurnal IImiah Akuntansi Fakultas Ekonomi), 7(2), 215-234. https://doi.org/ 10.34204/jiafe.v7i2.4072 
Neni Nurhayati: Faktor-faktor Pendukung ...

\section{PENDAHULUAN}

Pemerintah desa dituntut untuk mengelola keuangan desa sesuai dengan asas pengelolaan keuangan desa secara akuntabel, transparan dan partisipasi. Dana desa yang diberikan kepada pemerintah desa agar dikelola dengan benar sesuai dengan prosedur dan ketentuan yang diberikan oleh pemerintah pusat. Hal ini untuk mewujudkan desa yang maju, kuat, mandiri, serta memiliki kewenangan penuh dalam mengurus/mengatur diri sendiri untuk mencapai kesejahteraan masyarakat desa. Akuntabilitas keuangan desa tidak hanya bersifat horizontal antara pemerintah desa dengan Badan Permusyawaratan Desa (BPD), tetapi juga harus bersifat vertikal antara kepala desa dengan masyarakat desa dan atasan kepala desa, Dokumen publik tentang pengelolaan keuangan desa harus dapat diakses oleh masyarakat desa, serta tidak diskriminasi terhadap satu golongan tertentu terkait dengan pengelolaan keuangan desa (Yuliansyah, 2016).

Beberapa kasus korupsi Dana Desa (DD) dan Alokasi Dana Desa (ADD) yang dilakukan oleh mantan kepala desa khususnya di kecamatan Talaga dan Kecamatan Maja Kabupaten Majalengka diantaranya, pada tahun 2017 mantan Kepala Desa Jatipamor kecamatan Talaga Melakukan kecurangan terhadap bantuan keuangan pemerintah desa fasilitas peningkatan infrastruktur pedesaan tahun 2013 yang berasal dari Pemprov Jabar (Sugiharto, 2017). Tahun 2019 Mantan kepala desa Cihaur Kecamatan Maja Melakukan kecurangan terhadap Alokasi Dana Desa Tahun 2016 (Kurniawan, 2019).

Dari kasus tersebut, aparatur pemerintah desa khususnya kepala desa telah menyalahgunakan wewenang dalam penggunaan dana desa sehingga menyalahi aturan dan melanggar asas pengeloaan keuangan desa yang akuntabel dan transparan. Kasus tersebut menyalahi aturan atau indikator dari akuntabilitas keuangan desa. Menurut Lembaga Administrasi Negara (2015) mengemukakan bahwa terdapat empat dimensi akuntabilitas, yaitu akuntabilitas kejujuran dan hukum, akuntabilitas manajerial, akuntabilitas program dan akuntabilitas kebijakan. Beberapa peneliti terdahulu yang meneliti terkait faktor yang mempengaruhi akuntabilitas pengelolaan keuangan desa, di antaranya Sapartiningsih (2018) meneliti tentang kompetensi sumber daya manusia, pemanfaatan teknologi informasi, partisipasi masyarakat dan pengawasan terhadap akuntabilitas pengelolaan dana desa. Pahlawan dkk. (2020), meneliti pengaruh kompetensi aparatur desa, sistem pengendalian internal, pemanfaatan teknologi informasi dan partisipasi masyarakat terhadap akuntabililitas pengelolaan dana desa. Atiningsih (2019) melakukan penelitian tentang pengaruh kompetensi aparatur pengelola dana desa, partisipasi masyarakat, dan sistem pengendalian internal terhadap akuntabilitas pengelolaan dana desa. Penelitian ini mereplikasi penelitian terdahulu dengan berbeda objek penelitian dan menambah variabel intervening dalam mempengaruhi akuntabilitas pengelolaan keuangan desa.

Kualitas sumber daya manusia adalah kemampuan sumber daya manusia untuk melaksanakan tugas dan tanggung jawab yang diberikan kepadanya dengan bekal pendidikan, pelatihan, dan pengalaman yang cukup memadai. Hal ini untuk mewujudkan tata kelola yang baik dalam pemerintah desa. Tuntutan dari masyarakat dalam aspek pelayanan dan pekerjaan, menuntut aparatur desa untuk meningkatkan kompetensi sehingga akan dapat memahami tugas dan fungsi sebagai pengelola keuangan desa. Hal ini sejalan dengan penelitian yang dilakukan oleh Ramadhania \& Novianty (2020), dan Sapartiningsih (2018) yang menyatakan bahwa kualitas sumber daya manusia berpengaruh positif terhadap akuntabilitas pengelolaan keuangan desa. Namun hal ini tidak sejalan dengan penelitian yang dilakukan oleh Posi (2019) yang menyatakan bahwa kualitas sumber daya berpengaruh positif namun tidak signifikan terhadap akuntabilitas keuangan desa.

Penyelenggaraan pemerintah desa diharapkan akuntabel yang didukung dengan sistem pengawasan dan keseimbangan antara pemerintah desa dan lembaga desa (Puspawijaya \& Siregar, 2016). Lembaga yang berfungsi sebagai penyeimbang agar pemerintah desa tidak semena-mena dalam menetapkan suatu peraturan. Lembaga yang dimaksud adalah Badan Permusyawaratan Desa (BPD). Pemerintah desa dan BPD secara bersama-sama mengupayakan kemajuan dengan memberikan 
pengarahan, masukan, maupun pengawasan pada penyusunan serta penggunaan Anggaran Pendapatan dan Belanja Desa (APBD) dalam menetapkan peraturan pemerintah desa (Puspawijaya \& Siregar, 2016). Tata Kelola organisasi sektor publik akan berhasil apabila menerapkan tiga aspek yaitu pengawasan, pengendalian dan pemeriksaan. Ketiga hal tersebut pada dasarnya berbeda, baik konsepsi maupun aplikasinya (Mardiasmo, 2009). Penelitian terkait pengawasan telah dilakukan oleh Umaira \& Adnan (2019) dan Sapartiningsih (2018) yang menyatakan bahwa pengawasan berpengaruh positif terhadap akuntabilitas pengelolaan dana desa. Namun, hal ini tidak sejalan dengan penelitian yang dilakukan oleh Posi (2019) yang menyatakan bahwa pengawasan berpengaruh positif namun tidak signifikan terhadap akuntabilitas keuangan desa.

Partisipasi Masyarakat mempunyai peran penting dalam menyalurkan aspirasi, pemikiran, dan kepentingan dalam penyelenggaraan pemerintah desa. Partisipasi Masyarakat adalah keikutsertaan masyarakat dalam proses pengidentifikasian masalah dan potensi yang ada dimasyarakat, pemilihan dan pengambilan keputusan tentang alternatif solusi untuk menangani masalah, pelaksanaan upaya mengatasi masalah dan keterlibatan masyarakat dalam proses mengevaluasi perubahan yang terjadi (Adi, 2007). Penelitian terkait partisipasi masyarakat telah dilakukan oleh Dewi \& Gayatri (2019) dan Pahlawan dkk. (2020) yang menyatakan bahwa partisipasi masyarakat berpengaruh positif terhadap akuntabilitas pengelolaan dana desa.

Kualitas sumber daya manusia yang terampil sangat diperlukan dalam penggunaan suatu sistem. Mengingat aplikasi siskeudes merupakan suatu sistem informasi yang wajib digunakan bagi desa yang menerima dana desa serta berbasis komputerisasi, maka aparatur desa dalam hal ini adalah sekretaris desa selaku penanggung jawab mengelola administrasi desa dan bendahara desa selaku pembuat pertanggungjawaban laporan keuangan desa dituntut untuk mampu menguasai ilmu akuntansi dan komputer sehingga pelaporan pertanggungjawaban dana desa melalui aplikasi siskeudes menjadi lebih baik dan efektif (Wiguna, 2017). Dalam penelitian yang dilakukan Wiguna (2017) menyatakan bahwa kualitas sumber daya manusia berpengaruh signifikan terhadap efektivitas penggunaan siskeudes. Namun, hal ini tidak sejalan dengan penelitian yang dilakukan oleh Prasetya \& Diatmaja (2017) yang menyatakan bahwa kompetensi sumber daya manusia berpengaruh signifikan terhadap sistem keuangan desa namun dalam arah yang negatif. Penelitian terkait Aplikasi Sistem Keuangan Desa (Siskeudes) telah dilakukan oleh Puspasari \& Purnama (2018) yang menyatakan bahwa sistem keuangan desa merupakan aplikasi yang dikembangkan Badan Pengawasan Keuangan dan Pembangunan (BPKP) dalam rangka meningkatkan kualitas tata kelola keuangan desa (BPKP, 2016). Hal ini sejalan dengan dengan penelitian yang dilakukan oleh Harafonna \& Indriani (2019) yang menyatakan bahwa sistem keuangan desa berpengaruh terhadap akuntabilitas. Untuk menunjang tata kelola keuangan desa yang baik, pemerintah desa harus membangun sumber daya manusia yang berkualitas.

Pengelolaan keuangan desa masih minim pengawasan dan kurangnya pengetatan terhadap penggunaan anggaran. Fakta lapangan menunjukkan bahwa partisipasi publik terhadap pengelolaan keuangan desa masih terbatas dan kurang fokus. Penelitian mengenai pengaruh Pengawasan BPD terhadap sistem keuangan desa telah dilakukan oleh Prasetya \& Diatmaja (2017) yang menyatakan bahwa pengawasan berpengaruh positif dan signifikan terhadap kualitas penerapan sistem keuangan desa. Berdasarkan fenomena yang telah di uraikan, penelitian ini dianggap penting untuk dilakukan dengan objek lokasi yang berbeda dengan penelitian sebelumnya. Adapun tujuan penelitian ini untuk menghasilkan bukti empiris dan menganalisis pengaruh kualitas sumber daya manusia, pengawasan BPD dan partisipasi masyarakat terhadap akuntabilitas pengelolaan dana desa dengan sistem keuangan desa sebagai variabel intervening. 
Neni Nurhayati: Faktor-faktor Pendukung ...

\section{KAJIAN LITERATUR DAN PENGEMBANGAN HIPOTESIS Teori Stewardship}

Donaldson \& Davis (1991) menjelaskan bahwa "stewardship theory was designed for researches to examine situation in which excutives as steward are motivated to act in the best interest of their principals." Implikasi teori steward terhadap penelitian ini, yaitu dapat menjelaskan eksistensi pemerintah desa (yang bertindak sebagai steward) sebagai suatu lembaga yang dapat dipercaya dan bertindak sesuai dengan kepentingan publik dengan menjalankan tugas dan fungsinya untuk mewujudkan kesejahteraan masyarakat (yang bertindak sebagai prinsipal). Dalam hal ini, pemerintah desa (steward) memiliki kewajiban untuk memberikan informasi mengenai pengelolaan keuangan desa secara terbuka dan jujur yang dapat di akses dengan mudah oleh masyarakat (prinsipal). Untuk mewujudkan hal tersebut, maka diperlukan kualitas sumber daya yang baik selaku pengelola keuangan desa dengan BPD yang bertugas sebagai pengawas, serta melibatkan masyarakat dalam proses pengidentifikasian masalah dan pengambilan keputusan tentang alternatif solusi penyelesaian masalah.

\section{Kualitas Sumber Daya Manusia}

Kualitas sumber daya manusia menjadi salah satu faktor yang sangat penting dalam menciptakan good governance dalam pengelolaan keuangan desa. Dalam pengelolaan keuangan desa yang baik, pemerintah desa harus memiliki sumber daya manusia yang berkualitas, didukung dengan latar belakang pendidikan dan pelatihan, serta mempunyai pengalaman dibidang keuangan. Sehingga sumber daya manusia tersebut mampu memahami dengan baik dalam penerapan sistem akuntansi. Makin baik kualitas sumber daya manusia, maka akan makin akuntabel pengelolaan keuangan desa. Hal ini didukung oleh Penelitian Ramadhania \& Novianty (2020), Sapartiningsih (2018), dan Sugiarti \& Yudianto (2017) mengenai kualitas sumber daya manusia yang berpengaruh positif terhadap akuntabilitas pengelolaan keuangan desa.

Kualitas sumber daya manusia yang terampil sangat diperlukan dalam penggunaan suatu sistem. Mengingat aplikasi siskeudes merupakan suatu sistem informasi yang wajib digunakan bagi desa yang menerima dana desa serta berbasis komputerisasi, maka aparatur desa dalam hal ini adalah sekretaris desa selaku penanggung jawab mengelola administrasi desa dan bendahara desa selaku pembuat pertanggungjawaban laporan keuangan desa dituntut untuk mampu menguasai ilmu akuntansi dan komputer sehingga pelaporan pertanggungjawaban dana desa melalui aplikasi siskeudes menjadi lebih baik dan efektif. Makin baik kualitas sumber daya manusia, maka akan makin baik pula penggunaan sistem keuangan desa. Wiguna (2017) dan Nintyari dkk. (2019), Juardi \& Putri (2018), Saragih \& Kurnia (2018) menyatakan bahwa kualitas sumber daya manusia berpengaruh positif terhadap efektivitas penggunaan sistem keuangan desa. Maka hipotesis yang diajukan sebagai berikut.

$\mathrm{H}_{1}$ : kualitas sumber daya manusia berpengaruh positif terhadap akuntabilitas pengelolan keuangan desa

$\mathrm{H}_{5}$ : kualitas sumber daya manusia berpengaruh positif terhadap sistem keuangan desa

$\mathrm{H}_{8}$ : sistem keuangan desa memediasi pengaruh kualitas sumber daya manusia terhadap akuntabilitas pengelolaan keuangan desa

\section{Pengawasan BPD}

Pengawasan merupakan pemeriksaan dan pengendalian yang dilakukan sesuai dengan aturan dan kewenangan yang berlaku. Pengawasan sangat penting untuk menilai apakah anggaran yang digunakan sebagaimana mestinya sesuai dengan perencanaan yang telah ditentukan. Dalam pemerintah desa, pengawasan dilakukan untuk menjaga kegiatan operasi pemerintah desa sesuai dengan kebijakan yang telah ditetapkan guna mencapai tujuan pemerintahan desa. Sehingga pengawasan BPD ini dapat meningkatkan akuntabilitas pengelolaan keuangan desa. Jika pengawasan BPD terhadap pemerintah 
desa sesuai dengan tugasnya, maka potensi terjadinya kesalahan dan kecurangan juga akan makin kecil. Pemerintah desa harus mempertanggungjawabkan penggunaan dana desa kepada masyarakat yang menginginkan hasil kinerja yang baik dari pemerintah. Penelitian terkait hal ini telah dilakukan oleh Umaira \& Adnan (2019), dan Sapartiningsih (2018) yang menyatakan bahwa pengawasan berpengaruh positif terhadap akuntabilitas pengelolaan keuangan desa.

Pengawasan dilakukan untuk menjaga kegiatan operasi pemerintah desa sesuai dengan kebijakan yang telah ditetapkan guna mencapai tujuan pemerintahan desa. Mengingat pengelolaan keuangan desa masih minim pengawasan dan kurangnya pengetatan terhadap penggunaan anggaran terutama dalam penggunaan aplikasi sistem keuangan desa, maka peran BPD sangat diperlukan untuk mengawasi kinerja pemerintah desa terutama pengelola aplikasi sistem keuangan desa. Badan Permusyawaratan desa ikut berperan dalam mengawasi terhadap penggunaan aplikasi sistem keuangan desa. Penelitian mengenai pengaruh Pengawasan BPD terhadap sistem keuangan desa telah dilakukan oleh Prasetya \& Diatmaja (2017) yang menyatakan bahwa pengawasan berpengaruh positif terhadap penerapan sistem keuangan desa. Maka hipotesis yang diajukan sebagai berikut.

$\mathrm{H}_{2}$ : pengawasan BPD berpengaruh positif terhadap akuntabilitas pengelolaan keuangan desa

$\mathrm{H}_{6}$ : pengawasan BPD berpengaruh positif terhadap sistem keuangan desa

$\mathrm{H}_{9}$ : sistem keuangan desa memediasi pengaruh pengawasan BPD terhadap akuntabilitas pengelolaan keuangan desa

\section{Partisipasi Masyarakat}

Partisipasi Masyarakat merupakan keikutsertaan masyarakat dalam proses pengidentifikasian masalah dan pengambilan keputusan tentang alternatif solusi untuk menangani masalah, pelaksanaan upaya mengatasi masalah dan keterlibatan masyarakat dalam proses mengevaluasi perubahan yang terjadi. Partisipasi masyarakat juga bertujuan untuk mencapai hasil yang tepat sasaran dan mampu menciptakan kesejahteraan masyarakat dalam pengelolaan keuangan desa. Makin tinggi tingkat partisipasi masyarakat, maka akan makin tinggi pula rasa tanggung jawab pemerintah desa dalam melaksanakan akuntabilitas pengelolaan keuangan desa. Sebaliknya, jika tingkat partisipasi masyarakat rendah, maka akan makin rendah pula rasa tanggung jawab pemerintah desa yang dapat menyebabkan terjadinya penyalahgunaan dana desa. Makin tinggi partisipasi masyarakat, maka akan makin akuntabel pula pengelolaan keuangan desa. Penelitian terkait hal ini telah dilakukan oleh Dewi \& Gayatri (2019) yang menyatakan bahwa partisipasi masyarakat berpengaruh positif terhadap akuntabilitas pengelolaan dana desa.

Penggunaan aplikasi sistem keuangan desa dapat berperan dalam mewujudkan tata kelola keuangan desa yang baik, Makin aktif masyarakat dalam mengawasi penggunaan aplikasi sistem keuangan desa, maka akan makin baik pula kualitas penggunaan aplikasi sistem keuangan desa. Sehingga dapat disimpulkan bahwa partisipasi masyarakat berpengaruh terhadap sistem keuangan desa. Dalam hal ini, masyarakat dapat dilibatkan dalam pengidentifikasian masalah dan pengambilan keputusan tentang alternatif solusi penyelesaian masalah yang berkaitan dengan keuangan desa. Penelitian terkait hal ini telah dilakukan oleh Dewi \& Gayatri (2019) yang menyatakan bahwa partisipasi masyarakat berpengaruh positif terhadap akuntabilitas pengelolaan keuangan desa. Maka hipotesis yang diajukan sebagai berikut.

$\mathrm{H}_{3}$ : partisipasi masyarakat berpengaruh positif terhadap akuntabilitas pengelolaan keuangan desa

$\mathrm{H}_{7}$ : partisipasi masyarakat berpengaruh positif terhadap sistem keuangan desa

$H_{10}$ : sistem keuangan desa memediasi pengaruh partisipasi masyarkat terhadap akuntabilitas pengelolaan keuangan desa 


\section{Pengaruh Sistem Keuangan Desa Terhadap Akuntabilitas Pengelolaan Keuangan Desa}

Aplikasi sistem keuangan desa memiliki peran yang sangat penting dalam mengelola keuangan desa. Sistem keuangan desa dapat mempermudah dalam proses pelaporan pertanggungjawaban dan dapat menghasilkan laporan keuangan yang akuntabel. Sehingga, makin baik tingkat penggunaan aplikasi sistem keuangan desa, maka pengelolaan keuangan desa akan makin akuntabel. Hal ini sejalan dengan dengan penelitian yang dilakukan oleh Harafonna \& Indriani (2019), Saragih \& Kurnia (2018) dan Juardi \& Putri (2018) yang menyatakan bahwa sistem keuangan desa berpengaruh positif dan signifikan terhadap akuntabilitas pengelolaan keuangan desa. Hal ini menunjukkan bahwa penggunaan aplikasi sistem keuangan desa dapat berperan dalam mewujudkan tata kelola keuangan desa yang baik, makin baik penggunaan aplikasi sistem keuangan desa, maka akan makin akuntabel pula keuangan desa. Maka hipotesis yang diajukan sebagai berikut.

$\mathrm{H}_{4}$ : sistem keuangan desa berpengaruh positif terhadap akuntabilitas pengelolaan keuangan desa

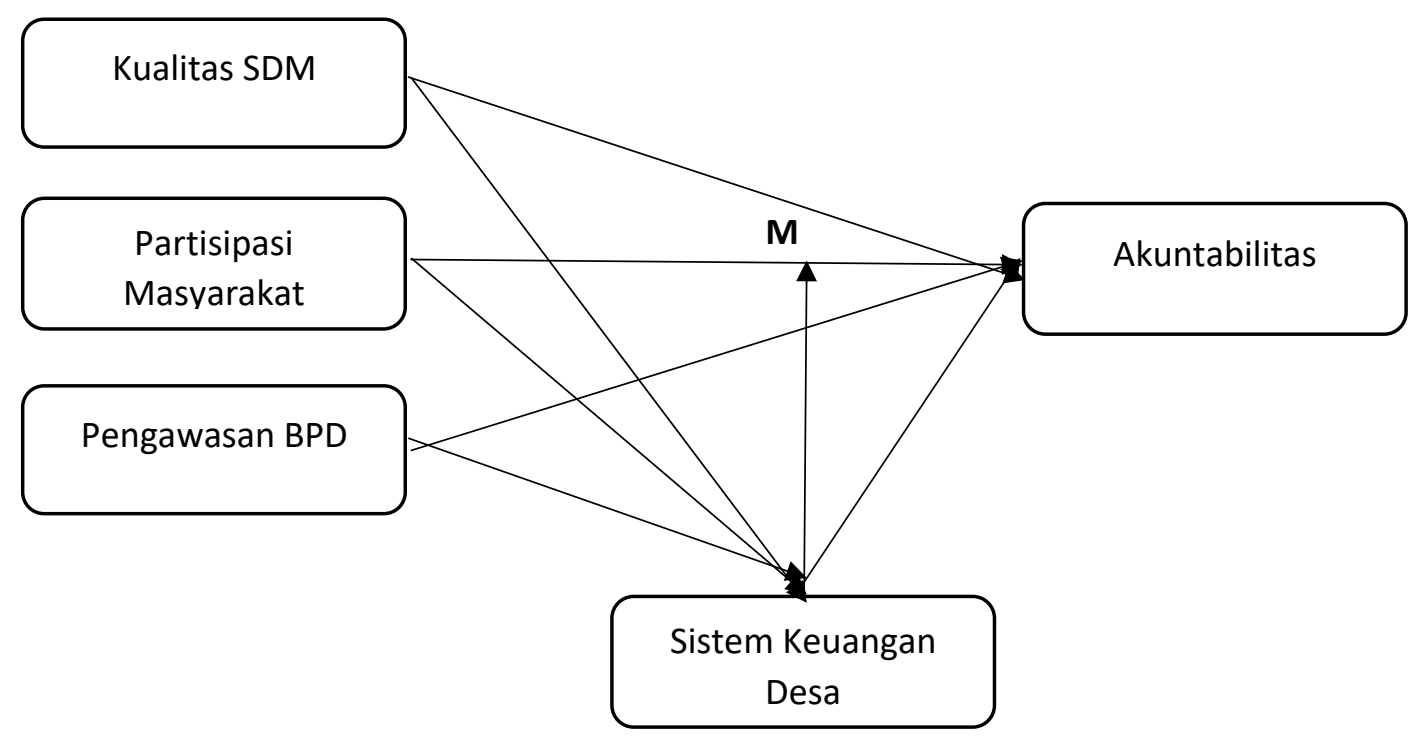

Gambar 1. Kerangka Berfikir

\section{METODE PENELITIAN}

Penelitian ini menggunakan metode deskriptif dan verifikatif. Populasi dalam penelitian ini adalah Pemerintah desa se-wilayah kecamatan Talaga dan Kecamatan Maja di Kabupaten Majalengka dengan unit analisis terdiri dari: Kepala desa, Kaur keuangan dan Badan Permusyawaratan Desa (BPD) sehingga jumlah keseluruhan responden sebanyak 105 responden. Sedangkan penentuan sampel dalam penelitian menggunakan metode sampel jenuh sebanyak 105 responden. Adapun operasional variabel dapat diuraikan tabel berikut. 
Tabel 1. Operasional Variabel

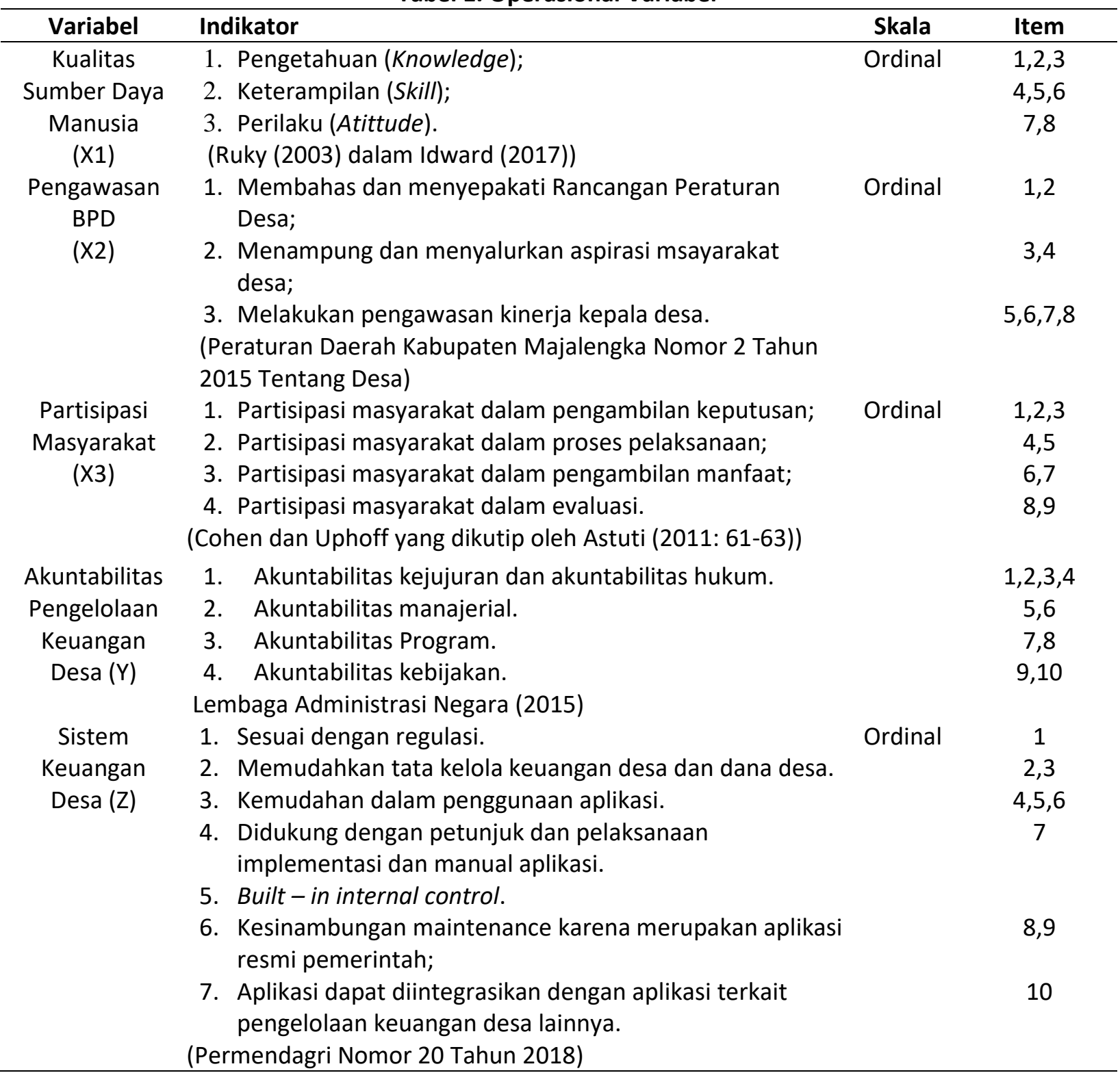

Jenis data yang digunakan dalam penelitian ini adalah data kualitatif yang diperoleh dari hasil isian kuesioner yang diberi bobot nilai (skala likert). Data yang digunakan dalam penelitian ini adalah data primer yang diperoleh dari hasil pengumpulan melalui kuesioner (angket) yang dibagikan kepada pemerintah desa pengelola keuangan desa. Teknik analisis data yang digunakan dalam penelitian ini adalah analisis deskriptif dan verifikatif yang meliputi uji asumsi klasik, analisis regresi berganda, koefisien determinasi serta uji hipotesis.

\section{HASIL DAN PEMBAHASAN}

Berdasarkan hasil pengujian yang dilakukan terhadap hasil pengisian kuisioner dari masing-masing variabel diperoleh hasil yang menunjukkan bahwa variabel kualitas sumber daya manusia, pengawasan 
BPD, partisipasi masyarakat, akuntabilitas pengelolaan keuangan desa, serta sistem keuangan desa adalah valid dan reliable. Karakteristik responden dapat dilihat pada Tabel 2.

Tabel 2. Karakteristik Responden

\begin{tabular}{ccc}
\hline Jenis Kelamin & Frekuensi (F) & Persentase (\%) \\
Laki-laki & 90 & 85,7 \\
Perempuan & 15 & 14,3 \\
Total & 105 & 100 \\
\hline Usia & & \\
$\leq 25$ tahun & 4 & 3,8 \\
$26-35$ tahun & 19 & 18,1 \\
$36-45$ tahun & 33 & 31,4 \\
$>45$ tahun & 49 & 46,7 \\
Total & 105 & 100 \\
\hline Pendidikan Terakhir & & \\
SD & 0 & 0 \\
SMP & 5 & 4,8 \\
SMA/SMK & 68 & 64,8 \\
Diploma & 4 & 3,8 \\
Sarjana & 28 & 26,7 \\
Pasca Sarjana & 0 & 0 \\
Total & 105 & 100 \\
\hline Masa Jabatan & & \\
< 5 tahun & 40 & 38,1 \\
>5 tahun & 65 & 61,9 \\
Total & 105 & 100 \\
\hline
\end{tabular}

Dari Tabel 2 dapat diketahui bahwa responden berjenis kelamin laki-laki yaitu sebanyak sembilan puluh orang atau $85,7 \%$ lebih banyak dibandingkan responden perempuan. Pada umumnya pekerja yang berjenis kelamin laki-laki lebih fokus dalam melaksanakan tugas dibandingkan perempuan yang cenderung memiliki tugas rumah tangga selain pekerjaannya. Responden berusia di atas 45 tahun yaitu sebanyak 49 orang atau $46,7 \%$ paling banyak dibandingkan responden katergori usia lain. Hal ini menunjukkan banyak pegawai yang ada pada usia mendektai pensiun. Responden berpendidikan SMA yaitu sebanyak 68 orang atau $64,8 \%$ paling lebih banyak diantara latar belakang pendidikan terakhir yang lain. Pada umumnya tingkat pendidikan menentukan kualitas dari respon dan wawasan seseorang. Responden dengan masa jabatan di atas lima tahun yaitu sebanyak 65 orang atau $61,9 \%$ paling banyak dibandingan masa jabatan lain. Lama masa jabatan dapat berimplikasi pada keahlian sesorang pada tugas pekerjaannya, makin lama masa jabatan cenderung makin ahli dalam melaksanakan pekerjaan tersebut. Rata-rata responden memiliki masa jabatan di atas lima tahun yang dapat diasumsikan para responden telah ahli dalam bidang pekerjaannya. Hal ini sejalan dengan usia responden yang sebagian besar ada di atas 49 tahun. 
Uji Validitas

Berikut disajikan tabel hasil pengujian validitas instrument penelitian.

Tabel 3. Hasil Uji Validitas

\begin{tabular}{cccccccccc}
\hline \multicolumn{2}{c}{ Kualitas SDM } & \multicolumn{2}{c}{ Pengawasan BPD } & \multicolumn{2}{c}{ Partisipasi Masy. } & \multicolumn{2}{c}{ Akuntabilitas } & \multicolumn{2}{c}{ Siskeudes } \\
\hline No & rhitung & No & rhitung & No & rhitung & No & rhitung & No item & rhitung \\
\hline 1 & 0,653 & 1 & 0,504 & 1 & 0,635 & 1 & 0,559 & 1 & 0,255 \\
2 & 0,708 & 2 & 0,629 & 2 & 0,754 & 2 & 0,649 & 2 & 0,477 \\
3 & 0,758 & 3 & 0,792 & 3 & 0,694 & 3 & 0,714 & 3 & 0,620 \\
4 & 0,708 & 4 & 0,762 & 4 & 0,640 & 4 & 0,641 & 4 & 0,813 \\
5 & 0,647 & 5 & 0,757 & 5 & 0,380 & 5 & 0,751 & 5 & 0,819 \\
6 & 0,575 & 6 & 0,648 & 6 & 0,741 & 6 & 0,817 & 6 & 0,827 \\
7 & 0,441 & 7 & 0,488 & 7 & 0,509 & 7 & 0,675 & 7 & 0,821 \\
8 & 0,647 & 8 & 0,690 & 8 & 0,468 & 8 & 0,718 & 8 & 0,514 \\
& & & & 9 & 0,628 & 9 & 0,662 & 9 & 0,505 \\
& & & & & & 10 & 0,644 & 10 & 0,598 \\
\hline
\end{tabular}

Dari Tabel 3 dapat diketahui bahwa hasil uji validitas untuk setiap item pernyataan dari masingmasing variabel menunjukkan lebih besar dari $r$ tabel 0,192 sehingga dapat disimpulkan bahwa item pernyataan untuk masing-masing variabel dinyatakan valid.

Tabel 4. Hasil Uji Reliabilitas

\begin{tabular}{lccc}
\hline \multicolumn{1}{c}{ Variabel } & $\begin{array}{c}\text { Nilai Cronbach's } \\
\text { Alpha }\end{array}$ & N of items & Keterangan \\
\hline Kualitas SDM & 0,778 & 8 & Reliabel \\
Pengawasan BPD & 0,810 & 8 & Reliabel \\
Partisipasi Masyarakat & 0,770 & 9 & Reliabel \\
Akuntabilitas & 0,871 & 10 & Reliabel \\
Sistem Keuangan Desa & 0,836 & 10 & Reliabel \\
\hline
\end{tabular}

Dari Tabel 4 dapat diketahui bahwa hasil uji reliabilitas untuk masing-masing variabel menunjukkan lebih besar dari $r$ tabel 0,192 sehingga dapat disimpulkan bahwa untuk masing-masing variabel dinyatakan reliabel.

\section{Analisis Deskriptif Kualitas Sumber Daya Manusia}

Berdasarkan hasil analisis deskripsi maka dapat disimpulkan bahwa kualitas sumber daya manusia pada seluruh Desa di Kecamatan Talaga dan Kecamatan Maja Kabupaten Majalengka termasuk dalam kategori sangat tinggi. Hal yang membuat kualitas sumber daya manusia dalam kategori sangat tinggi dapat dilihat dari skor tertinggi yaitu item 8 yang menyatakan aparatur pemerintah desa selalu bekerja dengan mengedepankan etika dan kode etik. 


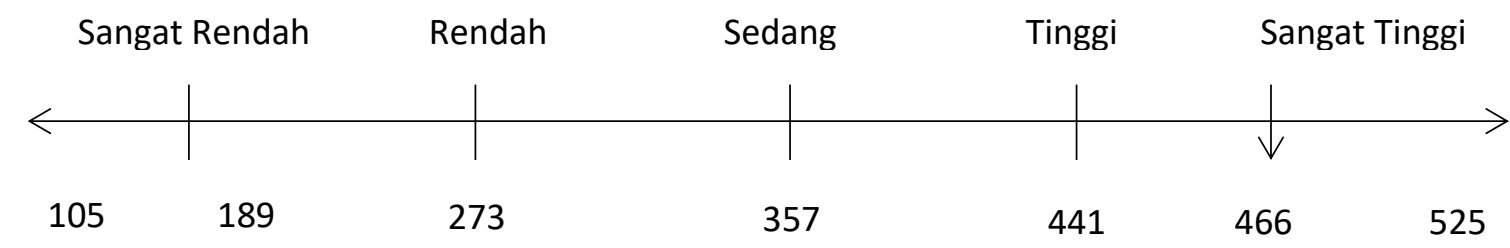

Gambar 1. Daerah Kriterium Variabel Kualitas Sumber Daya Manusia

Meskipun kualitas sumber daya manusia termasuk kategori sangat tinggi, hal ini masih belum maksimal karena masih adanya kendala yang dihadapi sebagaimana skor terendah, yaitu item satu menyatakan kurang mampu memahami siklus akuntansi dengan baik dalam pengelolaan keuangan desa.

\section{Analisis Deskriptif Pengawasan Badan Permusyawaratan Desa}

Berdasarkan hasil analisis deskripsi maka dapat disimpulkan bahwa pengawasan BPD pada seluruh Desa di Kecamatan Talaga dan Kecamatan Maja Kabupaten Majalengka termasuk dalam kategori sangat tinggi. Hal yang membuat pengawasan BPD dalam kategori sangat tinggi dapat dilihat dari skor tertinggi, yaitu item satu yang menyatakan funsgi BPD membahas dan menyepakati Rancangan Peraturan Desa bersama kepala Desa.

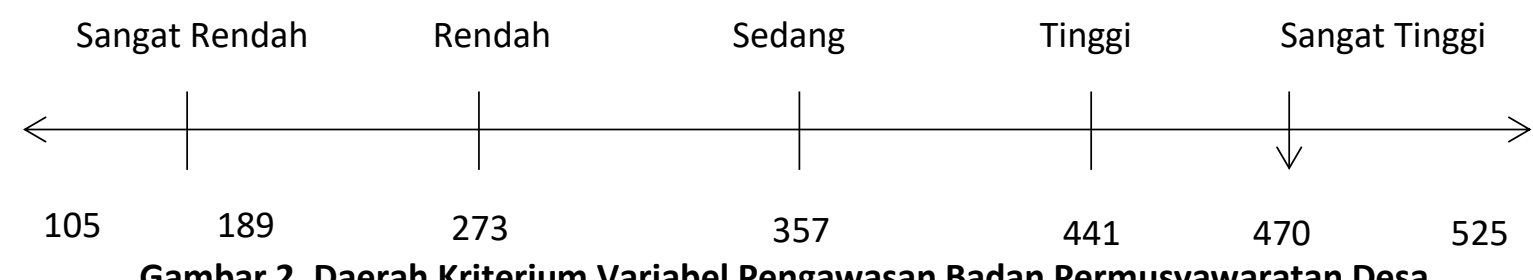

Meskipun kualitas pengawasan BPD termasuk kategori sangat tinggi, hal ini masih belum maksimal karena masih adanya kendala yang dihadapi sebagaimana skor terendah yaitu item 7 menyatakan BPD kurang melakukan pemeriksaan terhadap catatan akuntansi, fisik kas, dan barang dalam pengelolaan keuangan desa.

\section{Analisis Deskriptif Partisipasi Masyarakat}

Berdasarkan hasil analisis deskripsi maka dapat disimpulkan bahwa partisipasi masyarakat pada seluruh Desa di Kecamatan Talaga dan Kecamatan Maja Kabupaten Majalengka termasuk dalam kategori tinggi. Hal yang membuat partisipasi masyarakat dalam kategori tinggi dapat dilihat dari skor tertinggi yaitu item 2 yang menyatakan pemerintah desa selalu mendengarkan aspirasi masyarakat yang disampaikan pada saat rapat musrembang.

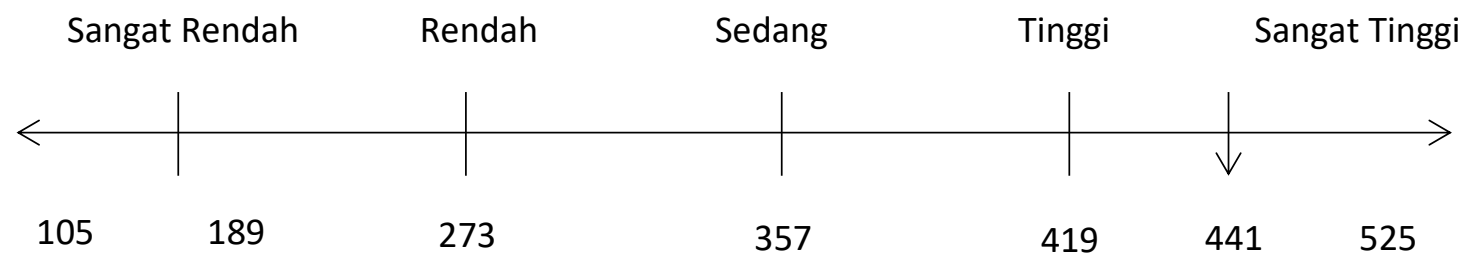

Gambar 3. Daerah Kriterium Variabel Partisipasi Masyarakat 
Meskipun partisipasi masyarakat termasuk kategori tinggi, hal ini masih belum maksimal karena masih adanya kendala yang dihadapi sebagaimana skor terendah yaitu item sembilan menyatakan pemerintah desa kurang menerima masukan dari masyarakat untuk perbaikan program selanjutnya dalam pengelolaan keuangan desa.

\section{Analisis Deskriptif Akuntabilitas Pengelolaan Keuangan Desa}

Berdasarkan hasil analisis deskripsi maka dapat disimpulkan bahwa akuntabilitas pengelolaan keuangan desa pada seluruh Desa di Kecamatan Talaga dan Kecamatan Maja Kabupaten Majalengka termasuk dalam kategori sangat tinggi. Hal yang membuat akutabilitas pengelolaan keuangan desa dalam kategori sangat tinggi dapat dilihat dari skor tertinggi yaitu item tiga yang menyatakan pemerintah desa mendapatkan sanksi dari pimpinan apabila telat dalam memberikan laporan keuangan.

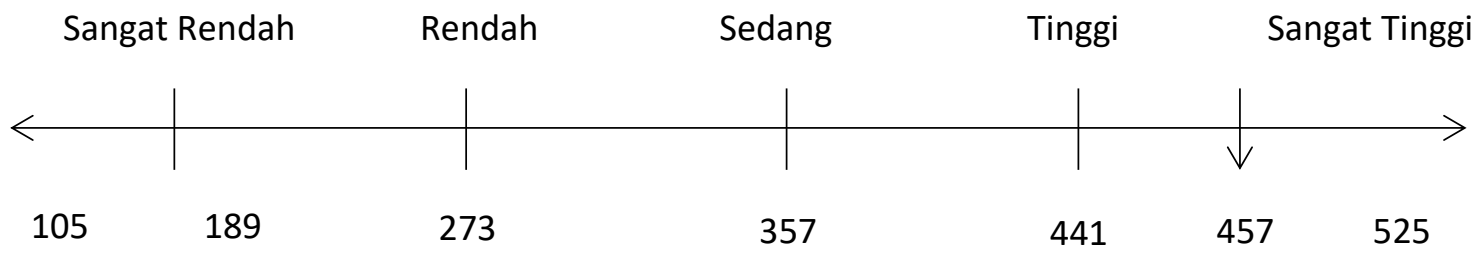

Gambar 4. Daerah Kriterium Variabel Akuntabilitas Pengelolaan Keuangan Desa

Meskipun akuntabilitas pengelolaan desa termasuk kategori sangat tinggi, hal ini masih belum maksimal karena masih adanya kendala yang dihadapi sebagaimana skor terendah yaitu item tujuh menyatakan pemerintah desa belum melaksanakan program sesuai dengan visi, misi dan tujuan yang sudah ditetapkan dalam pengelolaan keuangan desa

\section{Analisis Deskriptif Sistem Keuangan Desa}

Berdasarkan hasil analisis deskripsi, maka dapat disimpulkan bahwa sistem keuangan desa pada seluruh Desa di Kecamatan Talaga dan Kecamatan Maja Kabupaten Majalengka termasuk dalam kategori sangat tinggi.

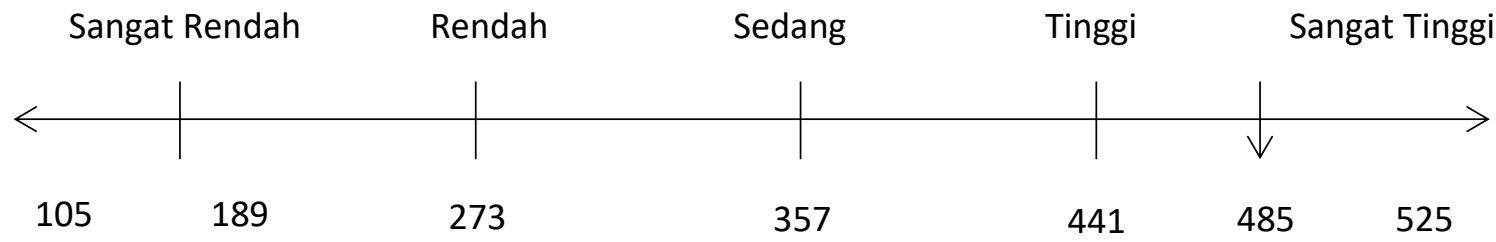

Gambar 5. Daerah Kriterium Variabel Sistem Keuangan Desa

Hal yang membuat sistem keuangan desa dalam kategori sangat tinggi dapat dilihat dari skor tertinggi yaitu item satu yang menyatakan Siskeudes merupakan aplikasi untuk membantu pengelolaan keuangan desa sesuai dengan Peraturan Pemerintah yang berlaku. Meskipun sistem keuangan desa termasuk kategori sangat tinggi, namun belum maksimal karena masih adanya kendala yang dihadapi sebagaimana skor terendah yaitu item empat menyatakan Siskeudes tidak mudah dipelajari dan tidak mudah dioperasikan dalam pengelolaan keuangan desa. 
Neni Nurhayati: Faktor-faktor Pendukung ...

\section{Uji Asumsi Klasik}

Dari tabel di atas, dapat diketahui bahwa nilai signifikansi Kolmogrov-Smirnov untuk kelima variabel penelitian masing-masing sebesar 0,$063 ; 0,075 ; 0,134 ; 0,218$; dan 0,640 . Nilai signifikansi kelima variabel tersebut lebih besar dari 0,05 sehingga data penelitian berdistribusi normal. Dengan demikian, analisis regresi layak digunakan.

Tabel 5. Uji Normalitas

\begin{tabular}{lccccc}
\hline & \multicolumn{2}{c}{ One-Sample Kolmogorov-Smirnov Test } & & \\
& $\begin{array}{c}\text { Kualitas } \\
\text { SDM }\end{array}$ & $\begin{array}{c}\text { Pengawasan } \\
\text { BPD }\end{array}$ & $\begin{array}{c}\text { Partisipasi } \\
\text { Masyarakat }\end{array}$ & Akuntabilitas & Siskeudes \\
\hline Kolmogorov-Smirnov Z & 1,315 & 1,280 & 1,162 & 1,052 & 1,313 \\
Asymp. Sig. (2-tailed) & 0,063 & 0,075 & 0,134 & 0,218 & 0,064 \\
\hline
\end{tabular}

Berikut adalah tabel hasil uji regresi linier berganda yang kemudian disusun formula sebagai berikut.

$$
Y=-5,540+0,338+0,242+0,520+0,1999
$$

Tabel 6. Analisis Regresi Linear Berdanda X terhadap Y

\begin{tabular}{lccc}
\hline \multicolumn{1}{c}{ Model } & B & T & Sig. \\
\hline (Constant) & $-5,540$ & $-1,536$ & 0,128 \\
Kualitas SDM & 0,338 & 2,564 & 0,012 \\
Pengawasan BPD & 0,242 & 2,113 & 0,037 \\
Partisipasi Masyarakat & 0,520 & 4,880 & 0,000 \\
Sistem Keuangan Desa & 0,199 & 2,171 & 0,032 \\
\hline
\end{tabular}

Kualitas sumber daya manusia memiliki nilai $t_{\text {hitung }}=2,564$ dengan signifikansi 0,012 . Karena $t_{\text {hitung }}>t_{\text {tabel }}$ dan signifikansi $<0,050$, maka Ho ditolak dan Ha diterima, artinya kualitas sumber daya manusia berpengaruh positif dan signifikan terhadap akuntabilitas pengelolaan keuangan desa. Pengawasan BPD memiliki nilai $t_{\text {hitung }}=2,113$ dengan signifikansi 0,037 . Karena $t_{\text {hitung }}>t_{\text {tabel }}$ dan signifikansi < 0,050, maka Ho ditolak dan Ha diterima, artinya pengawasan BPD berpengaruh positif dan signifikan terhadap akuntabilitas pengelolaan keuangan desa. Partisipasi masyarakat memiliki nilai $t_{\text {hitung }}=4,880$ dengan signifikansi 0,000 . Karena $t_{\text {hitung }}>t_{\text {tabel }}$ dan signifikansi $<0,050$, maka Ho ditolak dan Ha diterima, artinya partisipasi masyarakat berpengaruh positif dan signifikan terhadap akuntabilitas pengelolaan keuangan desa. Sistem keuangan desa memiliki nilai $t_{\text {hitung }}=2,171$ dengan signifikansi 0,032. Karena $t_{\text {hitung }}>t_{\text {tabel }}$ dan signifikansi $<0,050$, maka Ho ditolak dan Ha diterima, artinya sistem keuangan desa berpengaruh positif dan signifikan terhadap akuntabilitas pengelolaan keuangan desa.

Tabel 7. Analisis Regresi Linear Berganda X terhadap Z

\begin{tabular}{lccc}
\hline \multicolumn{1}{c}{ Model } & B & T & Sig. \\
\hline (Constant) & $-3,136$ &,- 804 & 0,423 \\
Kualitas SDM & 0,677 & 5,364 & 0,000 \\
Pengawasan BPD Desa & 0,425 & 3,641 & 0,000 \\
Partisipasi Masyarakat & 0,109 & 0,951 & 0,344 \\
\hline
\end{tabular}

Kualitas sumber daya manusia memiliki nilai $t_{\text {hitung }}=5,364$ dengan signifikansi 0,000 . Karena $t_{\text {hitung }}$ $>t_{\text {tabel }}$ dan signifikansi $<0,050$, maka Ho ditolak dan Ha diterima, artinya kualitas sumber daya manusia berpengaruh positif dan signifikan terhadap sistem keuangan desa. Pengawasan BPD memiliki nilai thitung 
$=3,641$ dengan signifikansi 0,000. Karena $t_{\text {hitung }}>t_{\text {tabel }}$ dan signifikansi $<0,050$, maka Ho ditolak dan Ha diterima, artinya pengawasan BPD berpengaruh positif dan signifikan terhadap sistem keuangan desa. Partisipasi masyarakat memiliki nilai $t_{\text {hitung }}=0,951$ dengan signifikansi 0,344 . Karena $t_{\text {hitung }}<t_{\text {tabel }}$ dan signifikansi $>0,05$, maka Ho diterima dan Ha ditolak, artinya partisipasi masyarakat berpengaruh positif terhadap sistem keuangan desa.

Tabel 8. Uji Sobel Kualitas Sumber Daya Manusia

\begin{tabular}{lc}
\hline Model & Hasil Uji Sobel \\
\hline 1 & 1,715 \\
\hline
\end{tabular}

Dari tabel di atas $t_{\text {hitung }}=1,715$ lebih besar dari $t_{\text {tabel }}=1,660$, maka dapat disimpulkan bahwa ada pengaruh mediasi. Sistem keuangan desa dapat memediasi pengaruh kualitas sumber daya manusia terhadap akuntabilitas pengelolaan keuangan desa.

Tabel 9. Uji Sobel Pengawasan BPD

\begin{tabular}{lc}
\hline Model & Hasil Uji Sobel \\
\hline 1 & 2,019 \\
\hline
\end{tabular}

Dari tabel di atas $t_{\text {hitung }}=1,563$ kurang dari $t_{\text {tabel }}=1,660$, maka dapat disimpulkan bahwa ada pengaruh mediasi. Sistem keuangan desa dapat memediasi pengaruh pengawaasan BPD terhadap akuntabilitas pengelolaan keuangan desa.

Tabel 10. Uji Sobel Partisipasi Masyarakat

\begin{tabular}{lc}
\hline Model & Hasil Uji Sobel \\
\hline 1 & 2,090 \\
\hline
\end{tabular}

Dari tabel di atas $t_{\text {hitung }}=2,090$ lebih besar dari $t_{\text {tabel }}=1,660$, maka dapat disimpulkan bahwa ada pengaruh mediasi. Sistem keuangan desa dapat memediasi pengaruh partisipasi masyarakat terhadap akuntabilitas pengelolaan keuangan desa.

\section{Pengaruh Kualitas Sumber Daya Manusia Terhadap Akuntabilitas Pengelolaan Keuangan Desa}

Hasil pengujian hipotesis menunjukkan bahwa kualitas sumber daya manusia berpengaruh positif terhadap akuntabilitas pengelolaan keuangan desa. Hasil penelitian tersebut menunjukkan bahwa makin berkualitas sumber daya pemerintah desa, maka makin akuntabel pengelolaan keuangan desa. Untuk mewujudkan pengelolaan keuangan desa yang baik, pemerintah desa harus memiliki aparatur desa yang berkualitas agar dalam bekerja lebih kompeten. Selain itu, pemerintah desa harus memfasilitasi untuk mengikuti pelatihan untuk menambah pengetahuan dan wawasan dalam pengelolaan keuangan desa, sehingga aparatur desa tersebut mampu memahami dengan baik. Hasil penelitian ini sejalan dengan penelitian yang telah dilakukan oleh Ramadan (2019), Sapartiningsih (2018) dan Sugiarti \& Yudianto (2017) yang menyatakan bahwa kualitas sumber daya manusia berpengaruh positif dan signifikan terhadap akuntabilitas pengelolaan keuangan desa.

\section{Pengaruh Pengawasan BPD Terhadap Akuntabilitas Pengelolaan Keuangan Desa}

Hasil pengujian hipotesis menunjukkan bahwa pengawasan BPD berpengaruh positif terhadap akuntabilitas pengelolaan keuangan desa. Hasil penelitian tersebut menjunjukkan bahwa makin baik peran BPD mengawasi pemerintah desa maka potensi terjadinya kesalahan dan kecurangan juga akan 
Neni Nurhayati: Faktor-faktor Pendukung ...

makin kecil. Hal ini menunjukkan bahwa makin baik pengawasan BPD, maka akan makin akuntabel pula pengelolaan keuangan desa. Adanya pengawasan mampu mencegah praktik-praktik yang menyimpang karena salah satu aspek pengawasan adalah pemeriksaan yang bertujuan untuk menilai apakah pelaksanaan kegiatan yang dilaksanakan sudah sesuai dengan peraturan yang berlaku. Pengawasan sangan penting untuk menilai apakah anggaran yang digunakan sebagaimana mestinya sesuai dengan perencanaan yang telah ditentukan. Dalam pemerintah desa, pengawasan dilakukan untuk menjaga kegiatan operasi pemerintah desa sesuai dengan kebijakan yang telah ditetapkan guna mencapai tujuan pemerintahan desa. Hasil penelitian ini sejalan dengan penelitian yang telah dilakukan oleh Umaira \& Adnan (2019) dan Sapartiningsih (2018) yang menyatakan bahwa pengawasan berpengaruh positif dan signifikan terhadap akuntabilitas pengelolaan dana desa.

\section{Pengaruh Partisipasi Masyarakat Terhadap Akuntabilitas Pengelolaan Keuangan Desa}

Hasil pengujian hipotesis menunjukkan bahwa partisipasi masyarakat berpengaruh positif terhadap akuntabilitas pengelolaan keuangan desa. Hasil penelitian tersebut menunjukkan bahwa makin tinggi tingkat partisipasi masyarakat, maka akan makin tinggi pula rasa tanggung jawab pemerintah desa dalam melaksanakan akuntabilitas pengelolaan keuangan desa. Hal ini menunjukkan bahwa makin tinggi partisipasi masyarakat, maka akan makin akuntabel pula pengelolaan keuangan desa. Salah satu prinsip good governance diantaranya adalah partisipasi masyarakat. Partisipasi masyarakat merupakan elemen penting dalam pengelolaan keuangan desa. Adanya partisipasi masyarakat dapat mendukung tugas pemerintah untuk mengidentifikasi kebutuhan masyarakat, mengatur agenda dan prioritas pelayanan, dan mengembangkan program-program pelayanan sesuai dengan kebutuhan dan aspirasi masyarakat. Partisipasi masyarakat juga bertujuan untuk mencapai hasil yang tepat sasaran dan mampu menciptakan kesejahteraan masyarakat dalam pengelolaan keuangan desa. Hasil penelitian ini sejalan dengan penelitian yang telah dilakukan oleh Dewi \& Gayatri (2019) dan Periansyah \& Sopiyan (2020) yang menyatakan bahwa partisipasi masyarakat berpengaruh positif dan signifikan terhadap akuntabilitas pengelolaan dana desa.

\section{Pengaruh Sistem Keuangan Desa Terhadap Akuntabilitas Pengelolaan Keuangan Desa}

Hasil pengujian hipotesis menunjukkan bahwa sistem keuangan desa berpengaruh positif dan signifikan terhadap akuntabilitas pengelolaan keuangan desa. Hasil penelitian tersebut menunjukkan bahwa penggunaan aplikasi sistem keuangan desa dapat berperan dalam mewujudkan tata kelola keuangan desa yang baik, makin baik penggunaan aplikasi sistem keuangan desa, maka akan makin akuntabel pula keuangan. Siskeudes dapat membantu aparatur pemerintah desa dalam melaporkan pertanggung jawaban pemerintah desa. Tujuannya agar menghasilkan laporan keuangan berkualitas. Dengan laporan keuangan yang berkualiatas akan berdampak pada akuntabilitas pengelolaan keuangan desa. Hasil penelitian ini sejalan dengan dengan penelitian yang dilakukan oleh Harafonna \& Indriani (2019), Saragih \& Kurnia (2018) dan Juardi \& Putri (2018) yang menyatakan bahwa sistem keuangan desa berpengaruh positif dan signifikan terhadap akuntabilitas pengelolaan keuangan desa.

\section{Pengaruh Kualitas Sumber Daya Manusia Terhadap Sistem Keuangan Desa}

Hasil pengujian hipotesis menunjukkan bahwa kualitas sumber daya manusia berpengaruh positif terhadap sistem keuangan desa. Hasil penelitian menunjukkan bahwa makin baik kualitas sumber daya manusia, maka akan makin baik pula penggunaan sistem keuangan desa. Banyaknya tuntutan dari pihak eksternal membuat aparatur pemerintah desa untuk memahami sistem keuangan desa karena sistem ini dapat membantu aparatur pemerintah dalam bekerja sehingga akan lebih fleksibel, efisien dan efektif dalam bekerja sehingga memudahkan dalam proses pelaporan keuangan desa dan pertanggung jawaban desa (Puspasari \& Purnama, 2018). Hasil penelitian ini sejalan dengan penelitian yang telah 
dilakukan Wiguna (2017) dan Nintyari dkk (2019) menyatakan bahwa kualitas sumber daya manusia berpengaruh positif dan signifikan terhadap efektivitas penggunaan sistem keuangan desa.

\section{Pengaruh Pengawasan Badan Perwusyawaratan Desa Terhadap Sistem Keuangan Desa}

Hasil pengujian hipotesis menunjukkan bahwa pengawasan BPD berpengaruh positif terhadap sistem keuangan desa. Hasil penelitian tersebut menunjukkan bahwa makin baik pengawasan BPD terhadap penggunaan sistem keuangan desa maka akan makin baik pula kinerja aparatur desa dalam menggunakan sistem keuangan desa. Adanya pengawasan mampu mencegah praktik-praktik yang menyimpang karena salah satu aspek pengawasan adalah pemeriksaan yang bertujuan untuk menilai apakah pelaksanaan kegiatan yang dilaksanakan sudah sesuai dengan peraturan yang berlaku. Pengawasan sangan penting untuk menilai apakah anggaran yang digunakan sebagaimana mestinya sesuai dengan perencanaan yang telah ditentukan.

Dalam pemerintah desa, pengawasan dilakukan untuk menjaga kegiatan operasi pemerintah desa sesuai dengan kebijakan yang telah ditetapkan guna mencapai tujuan pemerintahan desa. Mengingat pengelolaan keuangan desa masih minim pengawasan dan kurangnya pengetatan terhadap penggunaan anggaran terutama dalam penggunaan aplikasi sistem keuangan desa maka peran BPD sangat diperlukan untuk mengawasi kinerja pemerintah desa terutama dalam menggunakan aplikasi sistem keuangan desa. Hasil penelitian ini sejalan dengan penelitian yang telah dilakukan oleh Prasetya \& Diatmaja (2017) yang menyatakan bahwa pengawasan berpengaruh positif dan signifikan terhadap kualitas penerapan sistem keuangan desa.

\section{Pengaruh Partisipasi Masyarakat Terhadap Sistem Keuangan Desa}

Hasil pengujian hipotesis menunjukan partisipasi masyarakat berpengaruh positif terhadap sistem keuangan desa. Hal ini berarti bahwa sistem keuangan desa menjadi perhatian masyarakat desa karena mereka beranggapan bahwa sistem keuangan desa dipergunakan untuk melakukan Tindakan penyelewangan penggunaan dana desa dengan memanipulasi pada saat mengentri data di aplikasi sistem keuangan desa. Masyarakat biasanya ikut berpartisipasi dalam penyusunan rencana pembangunan jangka pendek maupun jangka panjang melalui musyawarah di setiap dusun sampai dengan tingkat desa. Selain itu, masyarakat akan lebih memperhatikan terkait dengan transaparansi dan akuntabilitas mengenai pengelolaan keuangan desa oleh aparatur pemerintah desa sehingga masyarakat berharap aparatur pemerintah desa menggunakan sistem keuangan desa sebagaimana mestinya yang dapat dimanfaatkan untuk kepentingan pelaporan keuangan yang transapran dan akuntabel bukan untuk menyalahgunakan demi kepentingan sendiri. Hal ini dukung oleh penelitian Ghani \& Septiari (2018) menyimpulkan bahwa partisipasi manager berpengaruh terhadap efektivitas sistem informasi akuntansi.

\section{Sistem Keuangan Desa Memediasi Pengaruh Kualitas Sumber Daya Manusia Terhadap Akuntabilitas Pengelolaan Keuangan Desa}

Hasil pengujian hipotesis menunjukkan bahwa sistem keuangan desa mampu memediasi pengaruh kualitas sumber daya manusia terhadap akuntabilitas pengelolaan keuangan desa. Hasil penelitian tersebut menunjukkan bahwa makin berkualitas sumber daya pemerintah desa, maka makin akuntabel pengelolaan keuangan desa dan penggunaan aplikasi sistem keuangan desa dapat berperan dalam mewujudkan tata kelola keuangan desa yang baik, makin baik penggunaan aplikasi sistem keuangan desa maka akan makin akuntabel pula keuangan desa. Dalam pengelolaan keuangan desa yang baik, pemerintah desa harus memiliki sumber daya manusia yang berkualitas, didukung dengan latar belakang pendidikan dan pelatihan, serta mempunyai pengalaman dibidang keuangan, sehingga sumber 
Neni Nurhayati: Faktor-faktor Pendukung ...

daya manusia tersebut mampu memahami logika akuntansi dengan baik dalam penerapan sistem akuntansi.

Kegagalan sumber daya manusia pemerintah desa dalam memahami dan menerapkan logika akuntansi akan berdampak pada kekeliruan laporan keuangan yang dibuat dan ketidaksesuaian laporan dengan standar yang ditetapkan pemerintah. Hasil penelitian ini sejalan dengan penelitian yang telah dilakukan oleh Ramadan (2019), Sapartiningsih dkk (2018) dan Sugiarti \& Yudianto (2017) yang menyatakan bahwa kualitas sumber daya manusia berpengaruh positif dan signifikan terhadap akuntabilitas pengelolaan keuangan desa, serta penelitian yang telah dilakukan Wiguna dkk (2017), dan Nintyari dkk (2019) menyatakan bahwa kualitas sumber daya manusia berpengaruh positif dan signifikan terhadap efektivitas penggunaan sistem keuangan desa.

\section{Sistem Keuangan Desa Memediasi Pengaruh Pengawasan BPD Terhadap Akuntabilitas Pengelolaan Keuangan Desa}

Hasil pengujian hipotesis menunjukkan bahwa sistem keuangan desa mampu memediasi pengaruh pengawasan BPD terhadap akuntabilitas pengelolaan keuangan desa. Hasil penelitian tersebut menunjukkan bahwa penggunaan aplikasi sistem keuangan desa dapat berperan dalam mewujudkan tata kelola keuangan desa yang baik, makin baik penggunaan aplikasi sistem keuangan desa dan makin kuat pengawasan BPD terhadap pengelola aplikasi sistem keuangan desa, maka akan makin akuntabel pula pengelolaan keuangan desa. Adanya pengawasan mampu mencegah praktik-praktik yang menyimpang karena salah satu aspek pengawasan adalah pemeriksaan yang bertujuan untuk menilai apakah pelaksanaan kegiatan yang dilaksanakan sudah sesuai dengan peraturan yang berlaku.

Hasil penelitian ini sejalan dengan penelitian yang telah dilakukan oleh Prasetya \& Diatmaja (2017) yang menyatakan bahwa pengawasan berpengaruh positif dan signifikan terhadap kualitas penerapan sistem keuangan desa, serta penelitian yang telah dilakukan oleh Harafonna \& Indriani (2019), Juardi \& Putri (2018), dan Saragih \& Kurnia (2018) yang menyatakan bahwa sistem keuangan desa berpengaruh positif dan signifikan terhadap akuntabilitas pengelolaan keuangan desa.

\section{Siskeudes Memediasi Pengaruh Partisipasi Masyarakat Terhadap Akuntabilitas Pengelolaan Keuangan Desa}

Hasil pengujian hipotesis menunjukkan bahwa sistem keuangan desa mampu memediasi pengaruh partisipasi masyarakat terhadap akuntabilitas pengelolaan keuangan desa. Hasil penelitian tersebut menunjukkan bahwa makin tinggi tingkat partisipasi masyarakat, maka akan makin tinggi pula rasa tanggung jawab pemerintah desa dalam mengelola aplikasi sistem keuangan desa. Adanya partisipasi masyarakat dapat memberikan masukan terhadap pemerintah desa untuk dalam merencanakan pembangunan jangka panjang maupun jangka pendek. Selain itu, masyarakat dapat mengawasi dan mengontrol pemerintah desa dalam pelayanan, dan mengembangkan program-program pelayanan sesuai dengan kebutuhan dan aspirasi masyarakat.

Partisipasi masyarakat juga bertujuan untuk mencapai hasil yang tepat sasaran dan mampu menciptakan kesejahteraan masyarakat dalam pengelolaan keuangan desa. Hasil penelitian ini sejalan dengan penelitian yang telah dilakukan oleh Dewi \& Gayatri (2019) yang menyatakan bahwa partisipasi masyarakat berpengaruh positif dan signifikan terhadap akuntabilitas pengelolaan dana desa, serta penelitian yang dilakukan oleh Harafonna \& Indriani (2019), Juardi \& Putri (2018), dan Saragih \& Kurnia (2018) yang menyatakan bahwa sistem keuangan desa berpengaruh positif dan signifikan terhadap akuntabilitas pengelolaan keuangan desa.

\section{KESIMPULAN}

Hasil penelitian menemukan bahwa kualitas sumber daya manusia, pengawasan BPD, partisipasi 
masyarakat, dan sistem keuangan desa berpengaruh positif terhadap akuntabilitas pengelolaan keuagan desa, kualitas sumber daya manusia dan pengawasan BPD berpengaruh positif terhadap sistem keuangan desa, partisipasi masyarakat tidak berpengaruh terhadap sistem keuangan desa, sistem keuangan desa mampu memediasi pengaruh kualitas sumber daya manusia, pengawasan BPD, dan partisipasi masyarakat terhadap akuntabilitas pengelolaan keuangan desa. Hal ini mengindikasikan bahwa sumber daya manusia, pengawasan BPD, partisipasi masyarakat dan sistem keuangan desa mempunyai dampak untuk mewujudkan asas pengelolaan keuangan desa yang akuntabel. Selain itu, dengan sumber daya manusia yang berkualitas dapat mengimplementasikan penggunaan sistem keuangan desa dalam menyelesaikan pekerjaan terkait dengan pelaporan maupun pertanggungjawaban keuangan desa.

Implikasi hasil penelitian ini bahwa untuk mewujudkan asas pengelolaan keuangan desa yang akuntabel diperlukan sumber daya manusia yang berkualitas, Badan Permusyawartan Desa bertugas mengawasi secara baik, dan selalu melibatkan masyarakat dalamrapat perencanaan pembangunan maupun pelaksanaan pembangunan desa secara jangka pendek maupun jangka panjang dan mengungkapkan penggunaan dana secara akuntabel dan transparan. Penelitian ini diharapkan dapat memberikan kontribusi dalam pengembangan ilmu di bidang akuntansi dan dijadikan referensi untuk riset yang akan datang. Dengan adanya penelitian ini, juga, diharapkan agar dapat memberikan gambaran yang jelas mengenai Akuntabilitas Pengelolaan Keuangan Desa mulai dari Kualitas Sumber Daya Manusia, Pengawasan BPD hingga Partisipasi Masyarakat desa sesuai dengan ketentuan yang berlaku melalui Sistem Keuangan Desa. Sebagai bahan masukan bagi pemangku kepentingan untuk memperbaiki masalah yang ada dan berdampak pada akuntabilitas pengelolaan keuangan desa yang makin efektif dan efisien, dan mengurangi adanya tindak pidana korupsi yang menjadi tolak ukur keberhasilan dalam Akuntabilitas Pengelolaan Keuangan Desa.

\section{DAFTAR PUSTAKA}

Adi, I, R. (2007). Intervensi Komunitas Pengembangan Masyarakat Sebagai Upaya Pemberdayaan Masyarakat. Jakarta: Rajawali Press.

Atiningsih, S. (2019). Pengaruh Kompetensi Aparatur Pengelola Dana Desa, Partisipasi Masyarakat, dan Sistem Pengendalian Internal Terhadap Akuntabilitas Pengelolaan Dana Desa. Jurnal IImu Manajemen dan Akuntansi Terapan, 1(1), 14-25. http://dx.doi.org/10.36694/jimat.v10i1.182

Badan Pemeriksa Keuangan Republik Indonesia. (2015). Peraturan Daerah Kabupaten Majalengka Nomor $22 \quad$ Tahun $2015 \quad$ Tentang Desa. https://peraturan.bpk.go.id/Home/Download/52868/Peraturan-Daerah-Nomor-2-Tahun-2015tentang-Desa.pdf

Badan Pengawasan Keuangan dan Pembangunan (BPKP). (2016). Aplikasi Sistem Keuangan Desa. http://www.bpkp.go.id/sakd/konten/2448/leaflet-simda-desa.bpkp

Donaldson, L., \& Davis, J.H. (1991). Stewardship Theory or Agency Theory: CEO Governance and Shareholder Returns. Australian Journal of Management, 16(1), 49-66. https://doi.org/10.1177/031289629101600103

Dewi, N. K. A. J. P., \& Gayatri. (2019). Faktor-Faktor Yang Berpengaruh Pada Akuntabilitas Pengelolaan Dana Desa. E-Jurnal Akuntansi, 16(2), 1269-1298

Ghani, I. A., \& Septiari, D. (2018). Pengaruh Partisipasi Manajer terhadap Efektivitas Sistem Informasi Akuntansi. Journal of Applied Managerial Accounting, 2(1), 65-70.

Harafonna, C. N., \& Indriani, M. (2019). Pengaruh Sistem Keuangan Desa terhadap Akuntabilitas Dengan Pengelolaan Keuangan Sebagai Variabel Intervening. Jurnal IImiah Mahasiswa Ekonomi Akuntansi., 4(2), 359-373 
Neni Nurhayati: Faktor-faktor Pendukung ...

Juardi, M., \& Putri. (2017). Evaluasi Penggunaan Sistem Keuangan Desa Dalam Upaya Peningkatan Akuntabilitas Keuangan Desa. Jurnal IImiah Akuntansi Peradaban, 4(1), 84-105.

Kurniawan, O. (2019, Juni 15). Korupsi Dana Desa, Mantan Kades di Majalengka Divonis 4 Tahun Penjara. Kumparan. https://kumparan.com/ciremaitoday/korupsi-dana-desa-mantan-kades-dimajalengka-divonis-4-tahun-penjara-1rHXAc1s0kl/full

Lembaga Administrasi Negara. (2015). Pedoman Penyusunan Pelaporan Akuntabilitas Kinerja Instansi Pemerintah. https://monev.bps.go.id/esakip/Pustaka/SK-LAN-239-2003-SAKIP.pdf

Mahmudi. 2015. Manajemen Kinerja Sektor Publik. Yogyakarta: UPP STIM YKPN.

Mardiasmo. 2009. Akuntansi Sektor Publik. Jakarta: Andi.

Nintyari, R. L., Kurniawan, P. S., \& Atmaja, A. T. (2019). Pengaruh Kompetensi Sumber Daya Manusia, Sosialisasi, Serta Manajemen Kontrol Terhadap Efektivitas dan Efisiensi Pelaksanaan Sistem Keuangan Desa (Siskeudes) (Studi Empiris Pada Desa-desa Penerima Dana Desa di Kabupaten Tabanan). JIMAT (Jurnal IImiah Mahasiswa Akuntansi), 10(2), 147-155.

Pahlawan, E. W., Wijayanti, A., \& Suhendro. (2020). Pengaruh Kompetensi Aparatur Desa, Sistem Pengendalian Internal, Pemanfaatan Teknologi Informasi dan Partisipasi Masyarakat terhadap Akuntanbilitas Pengelolaan Dana Desa. Indonesia Accounting Journal, 2(2), 162-172.

Periansyah \& Sopiyan, AR. (2020). Dampak Kompetensi dan Partisipasi Masyarakat terhadap Akuntabilitas Pengelolaan Dana Dasa Kecamatan Rambutan. Jurnal Riset Terapan Akuntansi, 4(1), 12-19. https://doi.org/10.5281/zenodo.3865151

Posi, P. (2019). Faktor-Faktor Yang Mempengaruhi Akuntabilitas Keuangan Desa Pada Pemerintah Kecamatan Morotai Selatan. Seri Ilmu-ilmu Sosial dan Kependidikan, 3(2), 76-86.

Prasetya, P., \& Diatmadja. (2017). Pengaruh Kompetensi Sumber Daya Manusia, Pemahaman, dan Pengawasan Terhadap Kualitas Sistem Keuangan Desa di Kabupaten Buleleng. e-jurnal S1 AK Universitas Pendidikan Ganesha, 8(2). http://dx.doi.org/10.23887/jimat.v8i2.14758

Puspasari, O. R., Purnama, D. (2018). Implementasi Sistem Keuangan Desa dan Kualitas Laporan Keuangan Pemerintah Desa di Kabupaten Kuningan. Jurnal Kajian Akuntansi, 2(2), 145-159. http://dx.doi.org/10.33603/jka.v2i2.1719

Puspawijaya, A., \& Siregar, J. D. N. (2016). Pengelolaan Keuangan Desa. Bogor: Pusdiklatwas BPKP

Ramadhania, S., \& Novianty, I. (2020). Pengaruh Kompetensi Sumber Daya Manusia terhadap Peningkatan Akuntabilitas Kinerja Instansi Pemerintah. Proceeding The $11^{\text {th }}$ Industrial Research Workshop and National Seminar.

Sapartiningsih, S. (2018). Anlisis Pengaruh Kompetensi Sumber Daya Manusia, Pemanfaatan Teknologi Informasi, Partisipasi Penganggaran Dan Pengawasan Terhadap Akuntabilitas Pengelolaan Dana Desa. Jurnal Akuntansi dan Sistem Teknologi Informasi, 14(1), 100-114.

Saragih, N. S., \& Kurnia, D. (2018). Pengaruh Perangkat Desa Dan Sistem Akuntansi Keuangan Desa Terhadap Akuntabilitas Pengelolaan Keuangan Desa Kabupaten Serang. Juma Unsera: Jurnal Universitas Serang Raya, 1(1), 1-9.

Sugiarti, E., \& Yudianto, I. (2017). Analisis Faktor Kompetensi Sumber Daya Manusia, Pemanfaatan Teknologi Informasi, dan Partisipasi Penganggaran terhadap Akuntabilitas Pengelolaan Dana Desa. Prosceedings Profesionalisme Akuntan Menuju Sustainable Business Practice, 580-590.

Sugiharto, A. (2017, April 18). Diduga Selewengkan Dana Bantuan Desa, 2 Mantan Kades Ditahan. Radar Cirebon. https://www.radarcirebon.com/2017/04/18/diduga-selewengkan-dana-bantuan-desa-2mantan-kades-ditahan/

Umaira, A. (2019). Pengaruh Partisipasi Masyarakat, Kompetensi Sumber Daya Manusia, Dan Pengawasan Terhadap Akuntabilitas Pengelolaan Dana Desa (Studi Kasus Pada Kabupaten Aceh Barat Daya). Jurnal Ilmiah Mahasiswa Ekonomi Akuntansi (JIMEKA), 4(3), 471-481. 
JIAFE (Jurnal Ilmiah Akuntansi Fakultas Ekonomi)

https://journal.unpak.ac.id/index.php/jiafe
Vol. 7 No. 2, Des 2021, Hal. 215-234

P-ISSN: 2502-3020, E-ISSN: 2502-4159

Wiguna, Y. P. (2017). Pengaruh Kualitas Sumber Daya Manusia, Pendidikan dan Pelatihan, Serta Peran Pendamping Desa Terhadap Efektivitas Penggunaan Sistem Keuangan Desa (Siskeudes) (Studi Pada Desa Penerima Dana Desa di Kabupaten Buleleng). e-Journal Universitas Pendidikan Ganesha.

Yuliansyah, R. (2016). Akuntansi Desa. Jakarta: Salemba Empat. 
